\title{
Oxidation of an Exogenous Glucose Load Using Naturally Labelled ${ }^{13}$ C-Glucose
}

\author{
Effect of Butylbiguanide Therapy in Obese Mildly Diabetic Subjects \\ P. Lefebvre, A. Luyckx, F. Mosora, M. Lacroix, and F. Pirnay \\ Division of Diabetes, Institute of Medicine and Department of Atomic and Molecular Physics, University of Liège, \\ and Institut Provincial E. Malvoz, Liège, Belgium
}

\begin{abstract}
Summary. The effect of a 14 day-administration of butylbiguanide was investigated in a group of 10 obese patients with mild-to-moderate glucose intolerance. Glucose tolerance was significantly improved, while fasting blood glucose and plasma levels of free fatty acids, insulin and glucagon remained unchanged. The estimation of the amount of the oral glucose load oxidized into $\mathrm{CO}_{2}$ was performed by means of a recently described procedure using "naturally labelled ${ }^{13} \mathrm{C}$-glucose" as tracer. The curves depicting the oxidation of the exogenous glucose load were similar in shape and magnitude before and after administration of the biguanide; in the latter case, however, slightly higher rates of oxidation of exogenous glucose were recorded during the $2 \mathrm{nd}, 3 \mathrm{rd}$ and 4 th hours of the test. These data do not provide evidence that the biguanide-induced improvement in glucose tolerance in patients with mild-to-moderate glucose intolerance is associated with any inhibiting or delaying effect of this type of drug on intestinal absorption (and subsequent oxidation) of the exogenous glucose load. On the contrary, a slight, but statistically significant, increase in the oxidation of exogenous glucose has been observed after butylbiguanide.
\end{abstract}

Key words: Biguanide, butylbiguanide, diabẹtes, free fatty acids, glucagon, glucose, insulin, management, stable isotopes.

We have recently reported a procedure which allows estimation of the amount of an oral glucose load oxidized into $\mathrm{CO}_{2}$ in man [1-6]. The method includes the use of glucose "naturally labelled" [1] with the stable isotope, ${ }^{13} \mathrm{C}$.
The aim of the present paper is to report the application of this new and innocuous procedure to the study of the mechanism of the blood glucose lowering action of butylbiguanide in human diabetes. Despite a wide therapeutic use [7], the site(s) and mode(s) of action of biguanides remain controversial [8]. Several recent observations suggest that the biguanides might slow or inhibit the intestinal absorption of glucose [9-12], while various clinical or experimental reports indicate that these drugs may act by decreasing liver gluconeogenesis [13] or increasing peripheral utilization of glucose $[14,15]$. In the present study, we investigated the effect of a 14 day-administration of butyl-biguanide on the oxidation of an exogenous glucose load, using naturally labelled ${ }^{13} \mathrm{C}$-glucose, in a group of obese patients with mild-to-moderate glucose intolerance.

\section{Methods}

\section{Study group}

Ten obese patients ( 20 per cent or more in excess of their ideal body weight) served as experimental subjects (Table 1). All had normal liver and kidney function as evaluated by routine criteria. Four $\left(n^{\circ} 2\right.$, 3,5 , and 6) had moderate fasting hyperglycaemia (109 to $133 \mathrm{mg} \%$ ) and all had glucose intolerance according to standard criteria [16]. All subjects were investigated before and 14 days after biguanide therapy (butylbiguanide or Silubin-retard ${ }^{\circledR}, 100 \mathrm{mg}$ twice daily, the last dose being given two hours before the beginning of the second test). During the study, and for at least 3 days before the first test, the subjects were fed on a normal diet providing a minimum of $250 \mathrm{~g}$ of carbohydrate per day and no other medication than biguanide was provided. The 
Table 1. Clinical data

\begin{tabular}{|c|c|c|c|c|c|}
\hline $\begin{array}{l}\frac{\tilde{U}}{0} \\
\frac{0}{0} \\
\tilde{D}\end{array}$ & ڤ్ & $\underset{8}{5}$ & 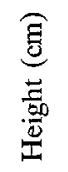 & 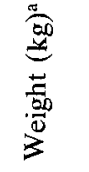 & 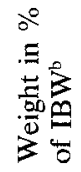 \\
\hline 1 & F & 27 & 163 & 102.5 & 192 \\
\hline 2 & $\mathrm{~F}$ & 60 & 155 & 81.5 & 163 \\
\hline 3 & $\mathbf{M}$ & 55 & 175 & 81.0 & 120 \\
\hline 4 & $\mathrm{~F}$ & 42 & 170 & 77.0 & 129 \\
\hline 5 & M & 54 & 172 & 79.0 & 124 \\
\hline 6 & $\mathrm{~F}$ & 49 & 155 & 67.0 & 134 \\
\hline 7 & $\mathrm{M}$ & 37 & 176 & 95.0 & 140 \\
\hline 8 & $\mathrm{~F}$ & 46 & 162 & 64.0 & 124 \\
\hline 9 & $\mathrm{M}$ & 25 & 165 & 82.0 & 136 \\
\hline $10^{c}$ & $F$ & 54 & 160 & 71.0 & 135 \\
\hline
\end{tabular}

a The weights of the patients were identical at the times of the two studies

b IBW: Ideal body weight according to the tables of the Metropolitan Life Ins. Co [40]

c No blood data were available in the second test for this patient

weights of the patients remained constant throughout the study. All subjects were fasted overnight before the test and all tests started at about $8 \mathrm{~A} . \mathrm{M}$.

\section{Glucose Tolerance Test}

In the standard oral glucose tolerance test (OGTT), $100 \mathrm{~g}$ of glucose (Glucopur, Glucoseries Réunies, Alost, Belgium) were administered in $400 \mathrm{ml}$ of water. Melting point determinations showed that this glucose was partially hydrated and calculations indicated that the amount of pure glucose in the load given was in fact $95 \pm 1 \mathrm{~g}$ (mean $\pm \mathrm{S}$. D., $\mathrm{n}=4$ ). This glucose, whose $\delta^{13} \mathrm{C}^{1}$ equals $17.8 \pm 0.3$ (mean \pm S. D., $n=4$ ) has a ${ }^{13} \mathrm{C}$ content greater than that normally found in human expired air [1]. Blood was sampled from an indwelling catheter inserted in an antecubital vein at 15 and 0 minutes before glucose ingestion and $30,60,90,120,150,180,210,240$, 270 and 300 minutes thereafter. The bladder was emptied before the test; all urine produced during the test was collected.

\footnotetext{
The relative abundance of ${ }^{13} \mathrm{C}$ and ${ }^{12} \mathrm{C}$ atoms in a sample is given by the formula of Craig [43]:

$\delta^{13} \mathrm{C}($ per $m l)=10^{3} \cdot \frac{{ }^{13} \mathrm{C} /{ }^{12} \mathrm{C} \text { sample }}{{ }^{13} \mathrm{C} /{ }^{12} \mathrm{C} \text { standard }}-1$

One unit of $\delta^{13} \mathrm{C}$ corresponds to a change of about $1.10^{-5}$ in the ratio ${ }^{13} \mathrm{C} /{ }^{12} \mathrm{C}$, and the precision of a measurement is \pm 0.2 unit of $\delta{ }^{13} \mathrm{C}$. We used as standard carbon sample 21 provided by the National Bureau of Standards (NBS 21)
}

\section{Blood and Urine Analysis}

Blood glucose was determined by the method of Hoffman [17] adapted to the Technicon AutoAnalyzer $^{(\beta)}$. Plasma free fatty acids (FFA) were determined by microtitration [18]. For hormone determination, $3.6 \mathrm{ml}$ of blood was added to $0.4 \mathrm{ml}$ of a solution containing Trasylol $^{\circledR} 5000 \mathrm{U} / \mathrm{ml}$ and $\mathrm{Na}_{2}$ EDTA $12 \mathrm{mg} / \mathrm{ml}$; the mixture was kept in an ice-bath until centrifugation at $4^{\circ} \mathrm{C}$. The separated plasma was stored at $-20^{\circ} \mathrm{C}$. Plasma glucagon was determined in duplicate by radioimmunoassay [19], using ${ }^{131} \mathrm{I}$-glucagon as tracer and $30 \mathrm{~K}$ antiserum (Dr.R.H. Unger, Dallas). Plasma insulin was assayed in duplicate by radioimmunoassay [20]. Urinary glucose was determined enzymatically using hexokinase (Biochemica Test ${ }^{\circledR}$, Boehringer $\mathrm{n}^{\circ}$ 15994).

\section{Expired Air Analysis}

The procedure has been described in detail elsewhere [5]. In brief, expired air was collected during $5 \mathrm{~min}$ every half-hour for the 7 hours following glucose ingestion; its $\mathrm{CO}_{2}$ content was determined using a Tissot gasometer and a respiratory mass spectrometer (Varian (MAT-M3); the ${ }^{13} \mathrm{C} /{ }^{12} \mathrm{C}$ ratio of this $\mathrm{CO}_{2}$ was analysed using a double-collector mass spectrometer (Varian MAT-CH5). This isotopic ratio is expressed as $\delta{ }^{13} \mathrm{C}$ which gives the enrichment in ${ }^{13} \mathrm{C}$ isotope of the sample relative to the reference $\mathrm{CO}_{2}$ (see foot-note ${ }^{1}$ ).

\section{Calculations}

The amount of exogenous glucose oxidized to $\mathrm{CO}_{2}$ was derived from the ${ }^{13} \mathrm{C} /{ }^{12} \mathrm{C}$ ratio in the glucose given, the ${ }^{13} \mathrm{C} /{ }^{12} \mathrm{C}$ ratio in the samples of expired air and the amounts of exhaled $\mathrm{CO}_{2}$, using calculations published elsewhere [5].

All data were analysed using the Student $t$ test for paired and non-paired data [21]. Unless otherwise stated, all results are expressed as mean \pm SEM.

\section{Results}

\section{Blood Glucose and Plasma FFA}

Basal blood glucose, averaging $99 \pm 7 \mathrm{mg} \%$ before and $97 \pm 7 \mathrm{mg} \%$ after treatment, was not affected by the 14 day-biguanide therapy. Glucose tolerance was significantly improved after butyl-biguanide (BuBG) (Fig. 1). The mean of the maximal blood 


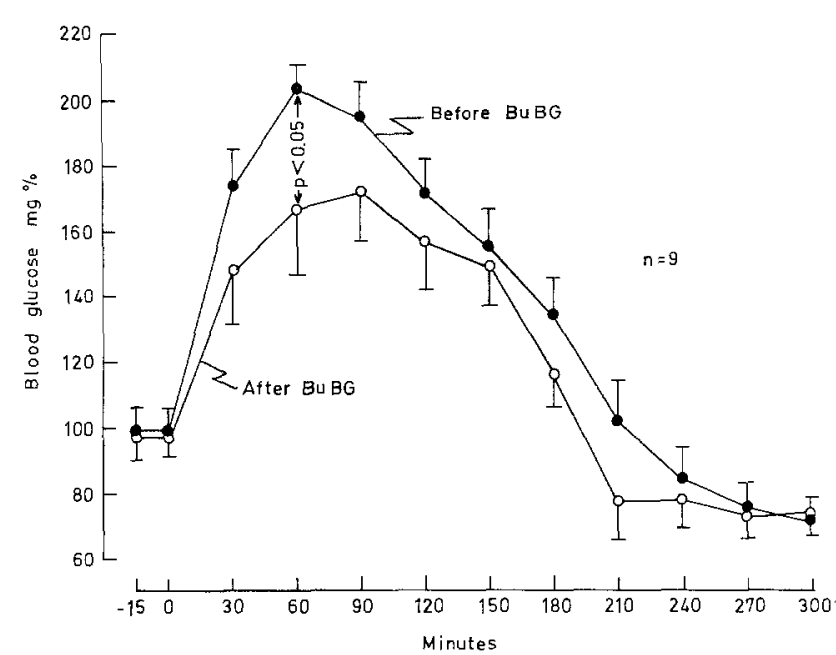

Fig. 1. Changes in blood glucose levels in the OGTT before and after butylbiguanide (BuBG). Results are expressed as mean \pm SEM

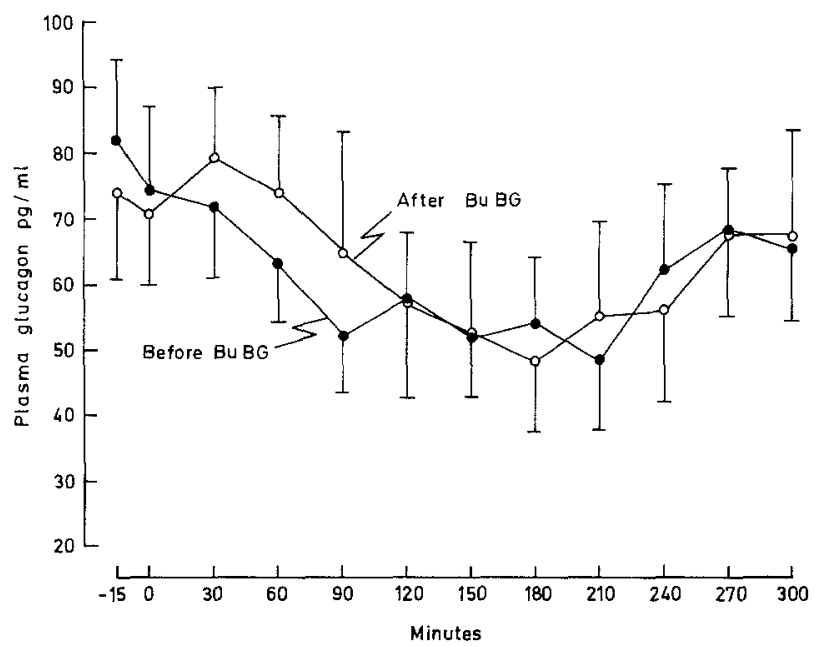

Fig. 3. Changes in plasma glucagon levels in the OGTT before and after butylbiguanide (BuBG). Results are expressed as mean $\pm \mathrm{SEM}$

glucose rises in each individual test was $208 \pm 9 \mathrm{mg}$ $\%$ before and $182 \pm 14 \mathrm{mg} \%$ after BuBG $(\mathrm{p}<0.05$ on paired comparison). Total glycosuria during the test was less than $1 \mathrm{~g} / 7$ hours in all patients (before or after $\mathrm{BuBG}$ ) with the exception of case $\mathrm{n}^{\circ} 3$ $(2.48 \mathrm{~g} / 7$ hours before $\mathrm{BuBG})$ and case $\mathrm{n}^{\circ} 5$ $(6.12 \mathrm{~g} / 7$ hours, before and $8.26 \mathrm{~g} / 7$ hours, after BuBG). Basal plasma FFA (mean of the samples collected at -15 and $0 \mathrm{~min}$ ) averaged $769 \pm 61$ $\mu \mathrm{mol} / 1$ before, and $706 \pm 64 \mu \mathrm{mol} / 1$ after BuBG, a difference which is not statistically significant. Oral glucose administration resulted in a profound de-

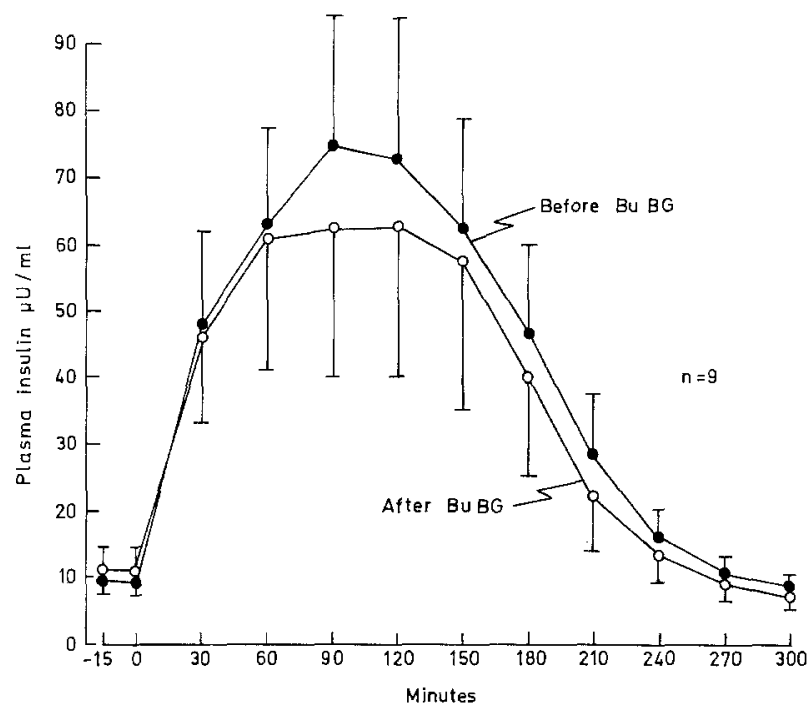

Fig. 2. Changes in plasma insulin levels in the OGTT before and after butylguanide (BuBG). Results are expressed as mean \pm SEM

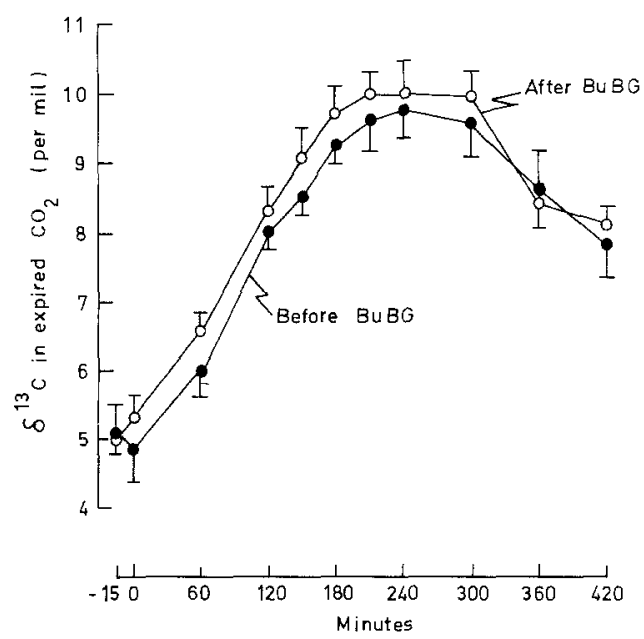

Fig. 4. Changes in the isotopic ratio ${ }^{13} \mathrm{C} /{ }^{12} \mathrm{C}$ (expressed as $\delta{ }^{13} \mathrm{C}$ ) in the expired air $\mathrm{CO}_{2}$ during the OGTT before and after butylbiguanide $(\mathrm{BuBG})$. Results are expressed as mean \pm SEM. Time 0 on the abscissa corresponds to the ingestion of glucose

pression of FFA plasma levels, similar in magnitude before $(298 \pm 31 \mathrm{mmol} / \mathrm{l})$ and after BuBG (325 $\pm 52 \mathrm{mmol} / 1)$. BuBG did not affect the secondary rise observed after the 210 th minute of the test.

\section{Plasma Insulin and Glucagon}

Basal plasma insulin was similar before $(9.5 \pm 2.4$ $\mu \mathrm{U} / \mathrm{ml})$ and after BuBG $(11.0 \pm 3.1 \mu \mathrm{U} / \mathrm{ml})$. The mean response to oral glucose was unaffected by BuBG (Fig. 2). Owing to marked individual variations in the insulin responses, the data were 
Table 2. Cumulative oxidation of exogenous glucose in the OGTT before and after butylbiguanide (BuBG)

\begin{tabular}{|c|c|c|c|c|c|c|c|}
\hline $\begin{array}{l}\text { Time from glucose ingestion } \\
\text { (hours) }\end{array}$ & $0-1$ & $0-2$ & $0-3$ & $0-4$ & $0-5$ & $0-6$ & $0-7$ \\
\hline \multicolumn{8}{|l|}{$\begin{array}{l}\text { Mean quantities of exogenous } \\
\text { glucose oxidized }(\mathrm{g})\end{array}$} \\
\hline Before BuBG & $0.66 \pm 0.15$ & $3.33 \pm 0.54$ & $7.93 \pm 1.04$ & $13.52 \pm 1.45$ & $19.01 \pm 1.71$ & $23.79 \pm 1.86$ & $27.57 \pm 2,02$ \\
\hline After BuBG & $0.98 \pm 0.13$ & $4.18 \pm 0.41$ & $9.58 \pm 0.85$ & $16.05 \pm 1.39$ & $22.20 \pm 1.93$ & $27.31 \pm 2.23$ & $31.13 \pm 2.44$ \\
\hline $\begin{array}{l}\text { Mean change after BuBG } \\
p \text { (paired } t \text { test) }\end{array}$ & $\begin{array}{l}+0.32 \pm 0.19 \\
\text { N.S. }\end{array}$ & $\begin{array}{l}+0.85 \pm 1.63 \\
\text { N.S. }\end{array}$ & $\begin{array}{l}+1.65 \pm 0.77 \\
\text { N.S. }\end{array}$ & $\begin{array}{l}+2.53 \pm 0.87 \\
<0.02\end{array}$ & $\begin{array}{l}+3.19 \pm 1.09 \\
<0.02\end{array}$ & $\begin{array}{l}+3.52 \pm 1.37 \\
<0.05\end{array}$ & $\begin{array}{l}+3.56 \pm 1.63 \\
\text { NS }\end{array}$ \\
\hline
\end{tabular}

a Results are expressed as mean $\pm \mathrm{SEM} ; \mathrm{n}=10$

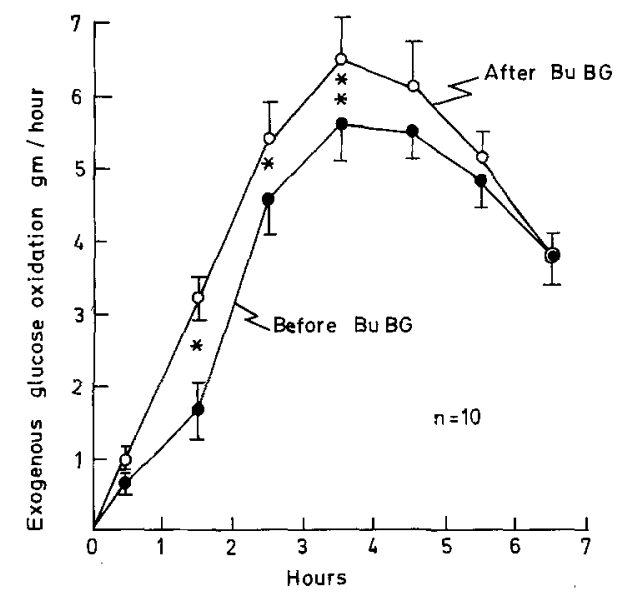

Fig. 5 Rates of exogenous glucose oxidation in the OGTT before and after butylbiguanide (BuBG). Results are expressed as mean \pm SEM; ${ }^{*} \mathrm{p}<0.05 ;{ }^{* *} \mathrm{p}<0.02$. Time 0 on the abscissa corresponds to the ingestion of glucose

analyzed by calculating the sum of insulin increments above basal levels at $30,60,90,120,150$ and $180 \mathrm{~min} .\left(\sum \mathrm{IRI}\right)$. This parameter averaged 312 $\pm 88 \mu \mathrm{U} / \mathrm{ml}$ before and $283 \pm 89 \mu \mathrm{U} / \mathrm{ml}$ after BuBG. The difference was not statistically significant by both non-paired and paired $t$ test analyses.

Basal plasma glucagon was similar before ( 78 $\pm 9 \mathrm{pg} / \mathrm{ml})$ and after BuBG $(73 \pm 8 \mathrm{pg} / \mathrm{ml})$. Oral glucose elicited a $40 \%$ reduction in plasma glucagon, a change which was not affected by biguanide (Fig. 3).

\section{Changes in $\delta^{13} \mathrm{C}$ in Expired $\mathrm{CO}_{2}$ and Evaluation of Exogenous Glucose Oxidation}

Biguanide therapy did not modify the natural abundance of ${ }^{12} \mathrm{C}$ and ${ }^{13} \mathrm{C}$ atoms in expired $\mathrm{CO}_{2}$ under basal conditions: $\delta{ }^{13} \mathrm{C}$ in expired air averaged $5.00 \pm 0.32$ before and $5.17 \pm 0.22$ after BuBG. As illustrated by Figure 4 , the administration of "naturally-labelled" ${ }^{13} \mathrm{C}$ glucose resulted in a rise in expired $\mathrm{CO}_{2} \delta{ }^{13} \mathrm{C}$ which was very similar before and after BuBG. As shown in Figure 5, the curve depicting the oxidation of the exogenous glucose load was similar in shape and magnitude before and after administration of biguanide: slightly higher rates of oxidation of exogenous glucose, however, were recorded during the 2 nd, 3 rd and 4 th hours of the test. Cumulative data on the oxidation of the exogenous glucose load are given in Table 2. Here again it appears that the total quantities of exogenous glucose oxidized are slightly but significantly increased in the BuBG-treated group after the third hour of the test.

\section{Discussion}

Stable isotopes are increasingly used for physiologi$\mathrm{cal}$, pathophysiological and pharmacological investigations [22]. Lacking any radiation hazards, they offer major advantages against radioactive isotopes as far as tracer studies are concerned [23, 24]. Glucose artificially enriched in ${ }^{13} \mathrm{C}$ is available for metabolic studies [23], but it is relatively rare and expensive. We have described the interest of "naturally labelled ${ }^{13} \mathrm{C}$-glucose" for metabolic studies in animals [25] and in man [1-6].

The higher concentration of ${ }^{13} \mathrm{C}$ atoms in some natural sugars is related to a selective isotopic effect occurring during photosynthesis in certain types of plants [25, 27]: the abundance of ${ }^{13} \mathrm{C}$ atoms in cane and maize sugar, from which the glucose used for OGTT is often manufactured, is higher than that of sugar derived from most other plants. In previous studies we have described the enrichment of expired $\mathrm{CO}_{2}$ in ${ }^{13} \mathrm{C}$ atoms after oral administration of "naturally labelled ${ }^{13} \mathrm{C}$-glucose" [1]. At rest in normal man, roughly $1 / 3$ of a $100 \mathrm{~g}$ load of glucose given by mouth was oxidized to $\mathrm{CO}_{2}$ in 7 hours [5].

In the present investigation we applied this procedure to the study of the mechanism of the blood lowering effect of butylbiguanide in human diabetes. 
We simultaneously determined blood glucose, plasma FFA, plasma insulin and glucagon in order to characterize precisely the group under study. The patients were selected on the basis of a mild-tomoderate glucose intolerance and of the presence of obesity. The reasons for this choice are: (1) this type of patient frequently represents an indication for biguanide therapy when diet alone has been proven to be ineffective (2) glycosuria during the test would be minimal at this degree of glucose intolerance and this would eliminate the presently unsolved problem of evaluating the amount of exogenous glucose lost in the urine. This isotopic enrichment of naturally labelled ${ }^{13} \mathrm{C}$-glucose is extremely low and currently available methods for extraction of glucose from a complex medium such as urine may involve isotopic effects which are as yet not fully evaluated. The biguanide selected for this investigation, butylbiguanide, is a drug used on a large scale in Europe and particularly in Germany [28]. It is usually considered as safer then phenylethylbiguanide as far as potential lactic acidosis is concerned [29] and it usually leads to less gastro-intestinal intolerance than dimethylbiguanide [30]. In the present investigation, the drug was well tolerated by all subjects.

After a 14 day-treatment with butylbiguanide, glucose tolerance was significantly improved while basal blood glucose, which was already near to normal before treatment, was unchanged. This finding is in agreement with previous reports [8]. Plasma FFA were unchanged both under basal conditions and after oral glucose. Their basal level was, as expected, higher than the one usually found in our laboratory for normal controls [31]. In contrast to the findings of other authors [8], we did not find decreased plasma insulin responses to oral glucose after biguanide administration. In agreement with Reaven et al. [32], we observed a marked heterogeneity in the insulin responses to oral glucose in this group of obese mildly diabetic patients. Plasma glucagon was unchanged after butylbiguanide. Both before and after treatment, oral glucose elicited a significant fall in plasma glucagon as it does in normal subjects. This finding suggests that the improvement in glucose tolerance induced by butyl biguanide is not due to a change in glucagon circulating levels. It confirms our previous finding that arginine-induced glucagon rise is not affected by biguanide (here dimethylbiguanide) treatment [33]. These data seem to rule out the possibilities that biguanide-induced improvement of glucose tolerance is mediated by changes in FFA, insulin or glucagon.

Among the numerous mechanisms evoked to explain the blood lowering effect of biguanides [34], the possibility that these drugs might act by inhibiting or slowing the intestinal absorption of glucose has been raised [9]. In fact, inhibition of giucose absorption has been demonstrated by perfusion techniques in vivo $[9,11,12]$ and also observed in vitro [10]. It has been suggested that biguanides might lower the ATP content of intestinal epithelial cells and thereby reduce the energy available for active transport [35]. In agreement with this theory is the apparent ineffectiveness of biguanides to improve glucose tolerance when infused intravenously $[8$, 36].

The method that we have described for evaluating the oxidation of an exogenous glucose load using naturally labelled ${ }^{13} \mathrm{C}$-glucose has limitations which we have previously discussed $[4,5]$. It provides indications about the amount of exogenous glucose carbons oxidized to $\mathrm{CO}_{2}$, independently of the metabolic pathways followed. It does not take into consideration factors such as equilibration between the glucose pools or changes in the bicarbonate- $\mathrm{CO}_{2}$ pool. As originally demonstrated by Krebs et al. [37] and discussed by Vranic [38] and Streja et al. [39] another difficulty arises because many metabolic pathways share common metabolic pools and "crossing over" of label occurs. In the example given by Krebs et al [37], the flux of ${ }^{14} \mathrm{C}$ from lactate to glucose underestimated the actual synthesis of glucose from lactate. This was due to an interchange of ${ }^{12} \mathrm{C}$ and ${ }^{14} \mathrm{C}$ in the oxaloacetate pool, a pool shared by the Krebs cycle and the gluconeogenic pathways: thus "the fate of the label does not allow predictions to be made about the net fate of the labelled metabolites" [37]. For similar reasons, in our experiments the calculation of exogenous glucose oxidation would probably represent an underestimate of true net glucose oxidation. The impact of this underestimate is probably minimized by the fact that our conclusions are based on the comparison of exogenous glucose oxidation in the same subjects under two different conditions. With these limiting factors in mind, the method has permitted us to estimate the amount of an exogenous glucose load of about $95 \mathrm{~g}$ completely oxidized to $\mathrm{CO}_{2}$ in normal individuals at rest as $28.4 \pm 1.4 \mathrm{~g}$ [5]. This value is very close to the one obtained, in the control OGTT, in the present group of obese patients with moderate glucose intolerance: 27.5 $\pm 2.0 \mathrm{~g}$. Urinary losses of glucose can be ignored since they were below $1 \mathrm{~g} / 7$ hours in 8 out of the subjects. These data might indicate that the oxidation of an exogenous glucose load given orally is very similar in normal subjects and in patients with mild glucose intolerance, a finding which is in agreement with recent results obtained using indirect 
calorimetry [40] or ${ }^{14} \mathrm{C}$-glucose turnover methods [41],

After butylbiguanide treatment, the lowering of the blood glucose curve after ingestion of the "naturally labelled ${ }^{13} \mathrm{C}$-glucose" is not accompanied by any delay in the appearance of the ${ }^{13} \mathrm{C}$ atoms in expired air $\mathrm{CO}_{2}$ (figure 4). Furthermore, neither the curves depicting the hourly rates of oxidation of exogenous glucose (figure 5) nor the calculations of the cumulative amounts of exogenous glucose oxidized (Table 2) indicate any lowering or delaying effect attributable to the biguanide treatment. On the contrary, a slight, but statistically significant, increase in the oxidation rate of exogenous glucose has been observed after butylbiguanide. Thus, our data do not provide evidence of any inhibiting or delaying effect of biguanides on intestinal glucose absorption (and subsequent exogenous glucose oxidation) in patients with mild-to-moderate glucose intolerance. They are compatible with an inhibitory effect of these drugs on hepatic glucose output or with a mild stimulation of peripheral utilisation of glucose or with both mechanisms.

Acknowledgements. This work was supported by the Fonds National de la Recherche Scientifique (FNRS), the Fonds de la Recherche Scientifique Médicale (FRSM), the Fonds de la Recherche Fondamentale Collective (FRFC) of Belgium and by a grant-in-aid of Chemie Grünenthal GMBH (West Germany). A. Luyckx is an Established Investigator of the F.N.R.S. We thank G. Lallemand and J. M. Delvaux for expert technical assistance and E. Vaessen-Petit for her secretarial assistance. We are indebted to M. Vranic (Toronto) for helpful advice and discussion and to M. Tunbridge for revision of the manuscript.

\section{References}

1. Lacroix, M., Mosora, F., Pontus M., Lefebvre, P., Luyckx, A., Lopez-Habib, G.: Glucose naturally labelled with carbon-13: use for metabolic studies in man. Science 181, 445-446 (1973)

2. Duchesne, J., Mosora, F, Lacroix, M., Lefebvre, P., Luyckx, A., Lopez-Habib, G.: Une application clinique d'une nouvelle méthode biophysique basée sur l'analyse isotopique du $\mathrm{CO}_{2}$ exhalé par l'homme. C. R. Acad. Sci. [D] (Paris) 277, 2261-2263 (1973)

3. Duchesne, J., Mosora, F., Lacroix, M., Lefebvre, P., Luyckx, A., Pirnay, F.: The study of diabetes using naturally enriched ${ }^{13} \mathrm{C}$-glucose. Proc. Second Internat. Conf. on Stable Isotopes, Oct. 20-23, 1975, Oak Brook (Ill.), p. 282-286. US Energy Research and Development Administration. Conf. 751027, 1976

4. Lefebvre, P., Mosora, F., Lacroix, M., Luyckx, A., LopezHabib, G., Duchesne, J.: Naturally labelled ${ }^{13} \mathrm{C}$-glucose. Metabolic studies in human diabetes and obesity. Diabetes 24, 185-189 (1975)

5. Mosora, F., Lefebvre, P., Pirnay, F., Lacroix, M., Luyckx, A., Duchesne, J.: Quantitative evaluation of the oxidation of an exogenous glucose load using naturally labelled ${ }^{13} \mathrm{C}$-glucose. Metabolism 25, 1575-1582 (1976)
6. Pirnay, F., Lacroix, M., Mosora, F., Luyckx, A., Lefebvre, P.: Glucose oxidation during prolonged exercise evaluated with naturally labelled ${ }^{13} \mathrm{C}$-glucose. J. Appl. Physiol. 43, 258-261 (1977)

7. Davidoff, F.: Guanidine derivatives in medicine. N. Engl. J. Med. 289, 141-146 (1973)

8. Berger, E. G., Moehr, P.: Oral versus intravenous administration of butylbiguanide: effect on oral glucose tolerance in normal humans. Eur. J. Clin. Invest. 6, 221-228 (1976)

9. Czyzyk, A., Tawecki, J., Sadowski, J., Ponikowska, I., Szcepanik, Z.: Effect of biguanide on intestinal absorption of glucose. Diabetes 17, 492-498 (1968)

10. Caspary, W.F., Creutzfeldt, W.: Analysis of the inhibitory effect of biguanides on glucose absorption: inhibition of active sugar transport. Diabetologia 7, 379-385 (1971)

11. Berger, W.: Die intestinale Wirkung der Biguanide. In: W. Berger, P. Waibel. Aktuelle Probleme der Angiologie, (Eds.): p. 104. Bern: Huber 1971

12. Lorch, E.: Inhibition of intestinal absorption and improvement of oral glucose tolerance by biguanide in the normal and the streptozotocin diabetic rat. Diabetologia 7, 195-204 (1971)

13. Meyer, F., Ipaktchi, M., Clauser, H.: Specific inhibition of gluconeogenesis by biguanides. Nature 213, 203-204 (1967)

14. Butterfield, J., Kelsey Fry, I., Holling, E.: Effect of insulin, tolbutamide and phenylethyl-biguanide on peripheral glucose uptake in man. Diabetes 7, 449-454 (1958)

15. Searle, G. L., Cavalieri, R. R.: Glucose kinetics before and after phenformin in the human subject. Ann. N. Y. Acad. Sci. 148, 734-742 (1968)

16. Wilkerson, H.L.C.: Diagnosis, oral glucose tolerance tests. In: Diabetes Mellitus: Diagnosis and Treatment pp. 31-34. New York: American Diabetes Association 1964

17. Hoffman, W.S.: A rapid photoelectric method for the determination of glucose in blood and urine. J. Biol. Chem. 120, 51-55 (1937)

18. Dole, V.P., Meinertz, H.: Microdetermination of long-chain fatty acids in plasma and tissues. J. Biol. Chem. 235, 2595-2599 (1960)

19. Luyckx, A. S.: Immunoassays for glucagon. In: P. J. Lefebvre, R.H. Unger (Eds): pp. 285-298. Glucagon, Molecular Physiology, Clinical and Therapeutic Implications. Oxford: Pergamon Press 1972

20. Quabbe, H. J.: Modifikation der radioimmunologischen Insulinbestimmung nach Hales and Randle. Diabetologia 5, 101-107 (1969)

21. Snedecor, G. W.: Statistical Methods, 5th Ed. Ames: Iowa State University Press 1976

22. Proceedings of the Second International Conference on Stable Isotopes, Oct. 20-23, 1975. Oak Brook (Ill.). Published by US Energy Research and Development Administration (Conference 751027), Washington 1976

23. Matwiyoff, N.A., Ott, D. G.: Stable isotope tracers in the life sciences and medicine. Science 181, 1125-1133 (1973)

24. Lefebvre, P.: L'utilisation des isotopes stables pour les investigations métaboliques chez l'Homme. Pathol. Biol. (Paris) 24, 303-305 (1976)

25. M. Lacroix: Thesis, University of Liège, 1972

26. Whelan, T., Sackett, W., Benedict, C.: Carbon isotope discrimination in a plant possessing the $\mathrm{C}_{4}$ dicarboxylic acid pathway. Biochem. Biophys. Res. Commun. 41, 1205-1210 (1970)

27. Smith, B., Epstein, S.: Two categories of ${ }^{13} \mathrm{C} /{ }^{12} \mathrm{C}$ ratios for higher plants. Plant Physiol. 47, 380-384 (1971)

28. Mehnert, C.L., Sadow, H.S.: The clinical use of hypoglycaemic guanidine derivatives. In: G.D. Campbell (Ed.) Oral Hypoglycaemic Agents pp. 247-294. London: Academic Press 1969 
29. Daubresse, J. C., Luyckx, A., Lefebvre, P.: Acidose lactique et thérapeutique par biguanides. Méd. et Hyg. 33, 1165-1168 (1975)

30. Daubresse, J.C., Luyckx, A., Lefebvre, P.: Intérêt du Nbutylbiguanide dans le traitement du diabète de la maturité. Rev. Med. Liège 30, 41-45 (1975)

31. Lefebvre, P.: Le glucagon seconde hormone pancréatique, p. 191. Paris: Maloine 1967

32. Reaven, G.M., Olefsky, J.M.: Relationship between heterogeneity of insulin responses and insulin resistance in normal subjects and patients with chemical diabetes. Diabetologia 12, 416 (1976)

33. Carpentier, J.L., Luyckx, A.S., Lefebvre, P. J.: Influence of metformin on arginine-induced glucagon secretion in human diabetes. Diab. Metab. 1, 23-28 (1975)

34. Sterne J.: Pharmacology and mode of action of the hypoglycaemic guanidine derivatives. In: G. D. Campbell (Ed.): Oral Hypoglycaemic Agents, pp. 193-245. London: Academic Press 1969

35. Bloch, R., Menge, H., Schaarschmidt, W. D., Gottesburg, H., Schaumlöffel, E., Göbell, H., Riecken, E. O.: Biochemische, histochemische, histologische und funktionelle Untersuchungen zur Phenforminwirkung auf die Dünndarmschleimhaut bei Ratte und Mensch. Klin. Wochenschr. 51, 235-241 (1973)

36. Polosa, P., Motta, M.: Etude de l'activité normoglycémiante de la metformine endoveineuse et orale chez le diabétique. Diabète (Le Raincy) 17, 33-37 (1969)

37. Krebs, H.A., Hems, R., Weidemann, M.J., Speake, R.N.: The fate of isotopic carbon in kidney cortex synthesizing glucose from lactate. Biochem. J. 101, 242-249 (1966)
38. Vranic, M.: Tracer methodology and glucose turnover: an overview. Fed. Proc. 33, 1837-1840 (1973)

39. Streja, D.A., Steiner, G., Marliss, E.B., Vranic, M.: The turnover and recycling of glucose in man during prolonged fasting. Metabolism 26, (in press) (1977)

40. Jequier, E., Pittet, Ph., Felber, J.P.: Contribution de la calorimétrie directe et indirecte à l'étude du métabolisme des glucides dans l'obésité et le diabète. In: Journ. Ann. Diabetol. Hôtel-Dieu, pp. 195-205. Paris: Flammarion 1976

41. Bowen, H.F., Moorhouse, I. A.: Glucose turnover and disposal in maturity-onset diabetes. J. Clin. Invest. 52, 3033-3045 (1973)

42. Metropolitan Life Insurance Company. Statistical Bulletin 40, Nov.-Dec. 1959, tables 2 and 3

43. Craig, H.: Isotopic standards for carbon and oxygen and correction factors for mass spectrometric analysis of $\mathrm{CO}_{2}$. Cosmochim. Acta 12, 133-149 (1957)

Received: March 30, 1977,

and in revised form: August 25, 1977

Dr. P. Lefebvre

Division of Diabetes

Institute of Medicine

University of Liège

Hôpital de Bavière

B-4020 Liège

Belgium 